\title{
4
}

\section{Toleration, justice and reason}

\author{
Rainer Forst
}

In contemporary debates about the idea and the problems of a multicultural society the concept of toleration plays a major but by no means clear and uncontested role. For some, it is a desirable state of mutual respect or esteem, while for others it is at best a pragmatic and at worst a repressive relation between persons or groups.

In the following, I want to suggest an understanding of toleration that both explains and avoids these ambiguities. First, I distinguish between a general concept and various more specific conceptions of toleration. ${ }^{1}$ This brief discussion shows that the concept of toleration is marked by two paradoxes that a conception of toleration should be able to resolve. On that basis, four paradigmatic conceptions of toleration are outlined, but I argue in favour of one of them, the 'respect conception', on normative grounds, while subsequently I draw out its epistemological implications. The central thesis that I put forward is that toleration is a virtue of justice and a demand of reason. The conclusion takes up again the two paradoxes mentioned at the beginning and how they are solved by the conception I propose.

\section{The concept of toleration and its paradoxes}

The general concept of toleration should be explained by six characteristics, which I shall briefly outline below.

(1) First, there is always a particular 'context of toleration'. This refers, on the one hand, to the relation between the tolerator and the tolerated: for instance, between parents and children, between friends, between members of a religious community, between citizens, and even between 'strangers', who share none of these more specific contexts. Depending on these contexts, the reasons for toleration and for its limits can differ. On the other hand, the question arises as to whether the subjects of toleration are individuals or groups or 'the state', as well as whether the objects of toleration are practices, single acts, or beliefs, to name just a few possibilities. 
(2) It is essential to the concept of toleration that the tolerated beliefs or practices are judged to be wrong or bad; following Preston King, this can be called the 'objection component'. ${ }^{2}$ If this component is absent, there is either indifference or affirmation - two attitudes that are incompatible with toleration. The objection must be normatively substantive, but is not necessarily restricted to 'moral' reasons; for, when discussing the concept of toleration generally, it would be inappropriate to exclude other forms of normative critique, such as, for instance, aesthetic critique. ${ }^{3}$

(3) Besides the 'objection-component', toleration requires a positive 'acceptance component' (also King's term), which does not cancel out the negative judgement but gives certain positive reasons which trump the negative ones in the relevant context. The said practices or beliefs, then, are considered to be wrong, but not intolerably wrong. In the case in which both the objection and the acceptance reasons are called 'moral', this leads to the much discussed paradox as to how it can be morally right or even a moral duty to tolerate what is morally wrong or bad. ${ }^{4}$ In order to resolve this paradox, a conception of toleration is required that explains the meaning of 'moral' - and of 'right' versus 'wrong' and 'bad' - in a differentiated way.

(4) The concept of toleration entails the idea of certain 'limits of toleration'. They lie at the point where reasons for rejection become stronger than the acceptance reasons (something that still leaves open the question of the appropriate means of intervention). It is important to see that the reasons for rejection need not be identical with the reasons for objection; ${ }^{5}$ they can be independent or (what is more likely) internally connected to the reasons of acceptance, which specify certain conditions and limits for that acceptance. It furthermore needs to be stressed that there are two limits involved here. The first one lies between the normative realm of the practices and beliefs one agrees with, and the realm of the tolerable practices and beliefs that one finds wrong but still can accept in a certain way. The second limit lies between this latter realm and the realm of the intolerable, which is strictly rejected (the limit of toleration properly speaking).

Another paradox emerges here, which is that toleration necessarily implies intolerance towards those who are seen as intolerable and, quite often, as intolerant as defined by those limits. The concept of tolerance makes no sense without certain limits, though as soon as these are substantively defined, tolerance seems to turn into nothing but intolerance. There is thus no 'true' tolerance. ${ }^{6}$ To avoid this paradox, a conception of toleration must be able to show how far its limits can be drawn in a mutually justifiable and non-arbitrary way.

(5) The exercise of toleration cannot result from compulsion, since the tolerating subjects would then be under an impossibility of voicing their objections and acting accordingly. If this were the case, they would merely 'endure' or 'suffer' certain practices or beliefs against which they are powerless. To conclude from this, however, that the tolerating party must be in 
a socially dominant position, having the power to interfere with the practices in question, is not justified. A minority that does not have this kind of power may still be tolerant and convinced that in the case in which it had such power it would not use it to the disadvantage of others. ${ }^{7}$

(6) Finally, toleration as a practice and tolerance as an attitude must be distinguished. A legal-political practice within a state that guarantees certain liberties to minorities can be called tolerant, as can also the personal attitude of accepting certain practices one finds objectionable. The former, though, can exist without the latter, for example where a state grants certain rights to minorities even though the majority of its citizens may disagree with such a policy, whilst the government acts on purely strategic motives. An analysis of toleration that is focused on the political-structural level of the peaceful coexistence of different cultural groups ${ }^{8}$ thus leaves open the crucial question as to what kind of attitude or virtue of tolerance citizens of a state can expect from one another.

\section{Four conceptions of toleration}

The following discussion of conceptions of toleration is not to be understood as a reconstruction of a linear historical development, nor should these conceptions be regarded as 'regimes of toleration' located in different historical and social circumstances. Rather, they represent different understandings of what toleration consists in, understandings that can be simultaneously present in a society, so that conflicts about the meaning of toleration may be understood as conflicts between these conceptions.9

The first one I call the permission conception. Here, toleration is a relation between an authority or a majority and a dissenting, 'different' minority (or various minorities). Toleration then means that the authority (or majority) gives qualified permission to the members of the minority to live according to their beliefs on the condition that the minority accepts the dominant position of the authority (or majority). As long as the expression of their difference is limited - that is, is an exercitium privatum, as it was traditionally called - and as long as the groups do not claim equal public and political status, they can be tolerated on both pragmatic and principled grounds. On pragmatic grounds, because this form of toleration is regarded as the least costly of all possible alternatives and does not disturb civil peace and order as the dominant party defines it (but rather contributes to it). On principled grounds, because one thinks it is morally wrong (and in any case fruitless) to force people to give up certain deep-seated beliefs or practices.

The permission conception is one that we find in many historical documents and precedents illustrating a politics of toleration (such as the Edict of Nantes in 1598 or the Toleration Act 1689) and that - to a considerable extent - still informs our understanding of the term. Here toleration means that the authority or majority, which has the power to interfere with the practices of a minority, nevertheless 'tolerates' them, while the minority 
accepts its dependent position. The situation or the 'terms of toleration' are non-reciprocal: one party allows another certain things on conditions that the first one specifies. Toleration appears in the sense of a permissio negativa mali: not interfering with something that is wrong but not 'intolerably' harmful. It is this conception that Goethe had in mind when he said: 'Tolerance should be a temporary attitude only: it must lead to recognition. To tolerate means to insult. ${ }^{10}$

The second conception, which can be called the co-existence conception, is similar to the permission conception in regarding toleration as the best means to end or avoid conflict. Here also toleration is not understood as a value in itself or as a moral duty: it is primarily justified in a pragmaticinstrumental way. Where the two conceptions differ, however, is in the constellation of power between the parties. With respect to the co-existence conception, its circumstances are not those in which an authority or majority stands over a minority, but rather one of groups, roughly equal in power, who see that for the sake of social peace and their own interests toleration is the best of all possible alternatives (a historical example is the Peace Treaty of Augsburg 1555). These groups prefer peaceful co-existence to conflict and agree to a reciprocal compromise, to a certain modus vivendi. The relation of tolerance is no longer vertical but horizontal: ${ }^{11}$ the subjects are at the same time the objects of toleration. Here, a state of mutual tolerance is preferred to conflict as a matter of practical necessity; thus coexistence toleration does not lead to a stable social situation in which trust can develop, because once the constellation of power changes, the reasons for being tolerant on the side of the more powerful group disappear. ${ }^{12}$ It is, however, possible that over time such a fragile modus vivendi can develop into a more stable system of co-existence and cooperation. ${ }^{13}$

The third conception of toleration - the respect conception - is one in which the parties tolerating each other respect one another in a more reciprocal sense: on moral grounds they regard themselves and others as citizens of a state in which members of all groups - majority or minorities - should have equal legal and political status. ${ }^{14}$ Even though they hold incompatible ethical beliefs about the good and right way of life, and differ greatly in their cultural practices, they respect each other as moral-political equals in the sense that their common framework of social life should - as far as fundamental questions of the recognition of rights and liberties and the distribution of resources are concerned - be guided by norms that all parties can equally accept, and that do not favour one specific 'ethical community'. ${ }^{15}$

There are two models of the respect conception: 'formal equality' and 'qualitative equality'. The former operates with a strict distinction between the political and the private realm, according to which ethical (i.e. cultural or religious) differences among citizens of a legal state should be confined to the private realm, so as to avoid differences and strife in the political sphere. As citizens, all are equal, and as political equals, they transcend their 
more narrow ethical beliefs. This version is clearly exhibited in the 'secular republicanism' (as I would call it) of the French authorities who held that headscarves with a religious meaning have no place in public schools in which children are educated to be autonomous citizens. ${ }^{16}$ But it can also be found in classical liberal views defending the priority and purity of equal subjective rights.

On the other hand, the model of 'qualitative equality' reacts to the problem that certain forms of formal equality favour those ethical-cultural communities whose beliefs and practices make it easier to accommodate the public/private distinction. In other words, the 'formal equality' model tends to be intolerant toward ethical-cultural forms of life that require a certain kind of public presence that others either do not require, or - as is most often the case - that require a public presence that differs from traditional and hitherto dominant cultural forms. Thus, on the 'qualitative equality' model, persons respect each other as political equals with distinct ethicalcultural identities that must be tolerated as (a) especially important for a person and (b) providing good reasons for certain exceptions from or changes to existing legal and social structures, in order to promote material and not just formal equality. Social and political equality and integration are thus seen to be compatible with cultural difference - within certain (moral) limits of reciprocity. ${ }^{17}$

In many debates on toleration, an additional conception is present, which I call the esteem conception. This implies an even fuller, more demanding notion of mutual recognition between citizens than that of the 'respect conception'. Accordingly, being tolerant does not mean respecting members of other cultural forms of life or religions as moral and political equals though objecting to their ethical ways of life. Rather, it means having some kind of ethical esteem for them; that is, regarding their beliefs as ethically valuable conceptions that are - even though different from one's own - in some way ethically attractive and held for good reasons. ${ }^{18}$ However, this conception must involve something like 'reserved esteem', that is, a kind of positive acceptance of a belief that for some reason one still considers to be less attractive than one's own. As valuable as aspects of the tolerated belief may be, it also has other aspects that are viewed as misguided or wrong, either from one's personal perspective or from a more objective point of view. ${ }^{19}$

The question now is: how do we decide which of these conceptions is the most justifiable? Should we prefer either the least or the most demanding conception in terms of mutuality of recognition? Given what has been said so far, it seems clear that the concept of toleration itself cannot provide us with an answer to this question, since we have just seen that there are many conceptions that can be plausibly called conceptions of toleration. Hence, I suggest that neither the concept of toleration nor a concept such as that of recognition can help us to decide this question: they are what I call 'normatively dependent concepts' that are in need of further, independent 
normative resources in order to have a certain substance and content. My thesis is that the concept of justice or, more specifically, a certain conception of justice in accordance with a notion of practical reason, can provide such a content.

\section{Justice and the threshold of reciprocity and generality}

The reason for my claim that a conception of justice is necessary in arguing for a conception of toleration is that the context in which the question of toleration between citizens arises is a context of justice: what is at issue here is the just - that is, mutually justifiable - legal and political structure for a pluralistic political community of citizens with different ethical beliefs. Claims for toleration are raised as claims for justice, and intolerance is a form of injustice, favoring one ethical community over others without legitimate grounds. ${ }^{20}$ Hence, toleration is a virtue of justice. My thesis is that, by considering the question of justice, I shall be in a position to show that, in its form of 'qualitative equality', the 'respect conception' is superior to the others.

To cut a long argument short, ${ }^{21}$ I think that at the centre of a conception of political and social justice there should be a theory of the intersubjective justification of norms that can reasonably - that is, with good reasons claim to be reciprocally and generally valid. The norms that regulate how the most important rights and resources are granted and distributed have to be justifiable with reasons that can be accepted equally by all citizens as free and equal persons.

The theory of 'public justification' that is thereby implied rests upon the criteria of reciprocity and generality. Reciprocity means that A cannot claim a right or a resource she denies to $B$ and that the formulation of the claim and the reasons given must be open to questioning and not be determined by one party only. If, invoking the principle of reciprocity, A says that it is right to force $\mathrm{B}$ to accept what $\mathrm{A}$ regards as true, since she herself would be happy to accept such an imposition, if she were in B's position with regard to the truth, she actually violates true reciprocity. A may believe that she knows and acts in favour of the truth - and something good and true for B also - but she puts the truth as she sees it beyond the demand for mutual justifiability, so that her truth claim turns into an attempt to dominate B. But nobody may deny others their basic (moral) right to justification, to be given adequate reasons for actions or norms that affect them in their status as free and equal persons. In connection with this, generality means that the reasons that are sufficient to support the validity of norms should not just be acceptable to, say, two dominant parties in a society (Protestants and Catholics, for example), but to every person and party involved. The realm of justification must be identical with the realm of the validity of a norm. This does not mean that there can be no valid norm until everybody has actually been persuaded to agree, for there will always 
be people who do not want to compromise their views and interests; rather, it means that a norm's validity is insufficiently established as long as the norm can be 'reasonably rejected' with reasons that are themselves reciprocally non-rejectable. ${ }^{22}$

Using the criteria of reciprocity and generality a distinction can be made between, on the one hand, justifiable general moral norms and, on the other, ethical values that cannot be generalised in this way but that may nevertheless be justifiably held as values guiding persons in many areas of their life. ${ }^{23}$ There is no reified distinction between 'value spheres' at work here, but rather a distinction between different 'contexts of justification' separated by what I call the threshold of reciprocity and generality. The basic question is whether a person can give reasons for her claims that can cross that threshold into the moral realm, or whether she fails in that because she appeals, for example, to a 'higher' truth that is revealed to her rather than arrived at through intersubjective argument ${ }^{24}$ and has to concede that the 'redemption' of her claim is dependent upon a particular ethical selfunderstanding and therefore not generally valid. ${ }^{25}$ Ultimately, the validity of ethical values for a person depends upon the affirmation of these values through this person in his or her particular ethical identity, and if this identification is not possible, the argument based on such values has no moral, categorical force to it. In disputes about the validity of a moral norm, however, one is required to raise, accept or reject normative claims with reasons that pass the test of reciprocity and generality. Only then can those claims have categorical force. Thus, whereas in the context of ethical justification it is ultimately you (on whatever 'higher' ground) who decides about the direction of your life, in the context of moral justification it is others to whom you owe good reasons.

Thus, if a particular ethical community tries to generalise some of its specific values and present them as a legitimate basis for general legislation, it must be able to explain why this is justified, given the legitimate interests of all others who have different identities and conceptions of the good. If the members of that community succeed in showing that they are not merely arguing in favour of their ideas of the good, which they want to make or keep socially dominant - forcing others to 'tolerate' their dominance from a minority position while they only want to 'tolerate' the minority as a different, though not politically equal, party - but that they argue in favour of goals all can agree to, then their claim is justified (for the time being). To give an example: ${ }^{26}$ arguments for homosexual marriage can be reciprocally justified as an extension of equal rights. In a context of general justification, this claim cannot legitimately be rejected with arguments that deny equal rights on the basis of particular ethical-religious views. Whereas such arguments are clearly reciprocally rejectable in a moral-political context, strong religious objections to certain ways of life are of course legitimate in an ethical context, where answers to the question of the good life are at issue. $^{27}$ 
Citizens are tolerant if they accept the boundary set by the criteria of reciprocity and generality as both delineating the justifiability of mutually binding norms and the limits of toleration. Tolerant citizens are 'reasonable' in accepting that the 'contexts of justification' for ethical beliefs and general norms are different: they see that an ethical objection does not amount to a legitimate moral rejection; and they also see that they have a moral duty to tolerate all those ethical beliefs and practices that they disagree with but that do not violate the threshold of reciprocity and generality (trying to force their views on others). Such a denial of the basic right to justification is a form of intolerance that cannot be tolerated. This is where the limits of toleration are reached.

It is in this sense that justice and reason are connected: persons recognise that with respect to questions of justice certain justifiable reasons have to be given according to validity criteria different from the ones in ethical contexts. Persons are tolerant to the extent that, even though they disagree with others about the nature of the good and true life, they tolerate all other views within the bounds of reciprocity and generality. This is why toleration is a virtue of justice and a demand of reason.

With respect to the four conceptions of toleration discussed above this means the following. As citizens, persons do have a right to have their ethical identity respected equally, yet they do not have a right to their ethical views' becoming the basis of general law. This is the main problem with the non-reciprocal 'permission conception', while the deficiency of the 'coexistence conception' is also that it insufficiently respects the basic right to justification. Potential weaknesses of one of the groups will therefore turn into a disadvantaged social position. Both conceptions fall short of the demand for mutual respect that a morally justifiable conception of toleration should start from.

Law based on reciprocally and generally justifiable norms can only be a 'protective cover' for diverse ethical identities if it is understood according to the 'qualitative equality' conception of respect referred to above. Given the range of differences among ethical beliefs and practices, equal respect does not mean imposing rigid formal equality, thereby relegating 'ethics' to the 'private realm'. Rather, it means that general social practices have to be sensitive to ethical differences - for example, to the particular demands of religious duties. Tolerating ethical difference thus implies mutual respect in this qualitative way - which is less than what is called for by the 'esteem conception'. In terms of justice, however, it calls for more than what the esteem conception allows, since the limits of toleration will not be drawn on the basis of an ethical judgement of the good: such a judgement creates the danger of drawing the limits too narrowly.

Yet at this point the normative discussion of toleration as an issue of justice has to shift and address the question of tolerance as a personal attitude of reasonable persons in more detail. How is this attitude possible? What notion of 'reason' is involved here? 


\section{The finitude of reason}

Every conception of tolerance implies a certain form of ethical selflimitation or 'self-relativisation'; and in the conception that I am proposing this is understood as a 'demand of reason'. But how can reason demand of me that I relativise my deeply held ethical beliefs in this way and accept that the reasons that are good ethical reasons for me are not (yet) good reasons in the context of general justification? Do I have to be a sceptic or a relativist or a 'comprehensive liberal' to accept this? That is, do I have to believe either in no ethical truth, or in the equality of different ethical beliefs, or in the value of ethical autonomy and the 'good life' of being a tolerant person? These are large questions, and I can only attempt to give a brief account of the notion of reason that I think is required to address them. The guiding idea is that such a capacity of reason is characteristic of people who accept the threshold of reciprocity and generality as a reasonable demand, without being sceptics, relativists, or comprehensive liberals. A theory of toleration must not be built upon such particular ethical points of view. Instead, what is needed is an account of reason that also applies to the 'reasonable' believer in some particular - say, religious - truth. What is required is a mild form of ethical self-relativisation as a reasonable attitude, and this must be neither strategically nor pragmatically motivated, nor justified as part of the person's idea of the good in a strong sense.

I call this form of ethical self-relativisation 'mild', because accepting the argumentative threshold of reciprocity and generality does not imply questioning the ethical truth of one's own beliefs, as opposed to a strong, almost schizophrenic, form of self-relativisation, according to which a tolerant person has to look at his or her convictions from an objective standpoint to assess their merits in terms of an 'impersonal' judgement. ${ }^{28}$ It is sufficient that a tolerant person be aware that there are different contexts of justification in which different questions (of the good life or of general norms) require different answers that have to satisfy different criteria of validity. Thus, a convincing answer to an ethical question may very well turn out to be a convincing answer to a general question of justice, though, on the other hand, it may not be. In the latter case, it can still be a convincing ethical answer that is not false in this context, even though it is not generally acceptable. It is in the nature of ethical beliefs that they are shaped by a number of particular experiences, which is why it would be unreasonable to assume them to be equally sharable among persons with very different experiental backgrounds. Hence it is unreasonable both to assume that there can be no reasonable ethical disagreement between persons capable and willing to seek a common normative answer given the two criteria of reciprocity and generality and to assume that the existence of reasonable disagreement in ethical matters makes it unreasonable or morally false to hold certain ethical beliefs, be they religious or not. ${ }^{29}$ The realm of the 
ethical, we may say, is much broader - and maybe also deeper - than the realm of the mutually non-rejectable. ${ }^{30}$

In his recent writings, John Rawls offers a productive explanation of this complex normative-epistemological attitude of reasonable and tolerant persons. According to Rawls, such individuals are aware of the 'burdens of reason' or 'burdens of judgment' that inevitably narrow the realm of what persons can reasonably agree to. Even those who are seeking to reach a normative consensus and who share 'a common human reason' in the sense that 'they can draw inferences, weigh evidence, and balance competing considerations ${ }^{31}$ may not reach a consensus owing to various limits on their capacities for reasonable theoretical and practical judgement. The most important burden Rawls mentions is that the way individuals assess evidence and weigh moral and political values is shaped by their total experience and whole course of life, which will always differ between persons, especially in modern, complex societies. His main point is that reasonable persons - who hold reasonable 'comprehensive doctrines' - are aware that they as well as others are subject to these burdens, which inevitably lead to disagreement between individuals who are influenced by very different experiences, normative backgrounds, and value horizons. Thus, it is not just a pragmatic and empirical insight that disagreement in normative matters may arise even between well-intentioned persons; it is a fundamental insight about the limitations of finite human reason.

The main reason-based argument for tolerance, therefore, is not the idea of a free and open competition of ideas and values that will separate truth from falsity in a process of inquiry. ${ }^{32}$ Rather, the insight into the presuppositions and the limits of such a competition constitutes the primary rationale for such an argument: that is, an insight into the irreducible finitude and plurality of human perspectives, and the limits of falsification in areas of beliefs that are not 'beyond reason' in terms of being irrational or not open to reasonable discourse, but that are 'beyond reason' in so far as they are based on reasons that may ultimately be neither verifiable nor falsifiable by human reason. One can both reasonably hold these beliefs and accept that others reasonably disagree with them. One believes in their truth while understanding that others do and may see things differently, given their perspective; thus one may try to convince others of one's beliefs, though one cannot force them upon others who are not unreasonable in holding other views. Hence 'being reasonable' includes epistemological as well as normative elements.

The epistemological element of being reasonable consists in an insight into the finitude of both theoretical and practical reason in finding 'final' answers to the question of the good that all can agree on. But it also consists in an insight into the possibilities of reason, that is, the capacity of reaching mutually justifiable normative answers. The finitude of reason does not imply the impossibility of reasonable discourse, but rather the task of finding and defending justifiable reasons, because this is what reasonable 
and finite persons - who cannot avoid raising general validity claims in their social life - owe to each other. This commonality establishes a community of sharable, but not ultimate reasons. ${ }^{33}$ Thus the normative element of being reasonable implies this form of respect for others as reasonable and worthy of being given adequate reasons; that is, respect for their basic right to justification. Both elements in combination, the epistemological and the normative, are the basis for the acceptance and recognition of the threshold of reciprocity and generality as discussed above. They provide the essential reasons for being tolerant. Being tolerant thus means seeking reasonable justification, accepting reasonable disagreement within the limits of reciprocity and generality, and being aware of the different contexts of justification that persons are part of. It implies tolerating other beliefs within these limits by not rejecting them as unreasonable or immoral, though it does not imply a qualification of the ethical truth of one's own beliefs. Taken together, then, the epistemological and the normative elements explain my definition of toleration as a demand of reason and a virtue of justice. ${ }^{34}$

\section{Resolving the paradoxes}

In conclusion, let me briefly return to the two paradoxes of toleration outlined at the beginning and see whether the conception I have proposed can resolve or avoid them.

Briefly stated, the first paradox consists in the problem of how it can be morally right to tolerate what is morally wrong. Given the discussion above, one can say that it is morally required of reasonable persons to justify norms that they think should be generally binding for everyone with reciprocally and generally justifiable reasons. It is in this sense that they must respect the epistemic and moral autonomy of other persons with ethical beliefs different from their own - that is, beliefs that they may disagree with and even find ethically wrong and insufficient as answers to questions of the good life, but that they cannot accuse of violating the boundary set by the criteria of reciprocity and generality. It is morally required and right to tolerate what you find ethically disagreeable and wrong within the limits of reasonableness and reciprocity that all have to accept; the fact that you find some beliefs and practices ethically wrong does not make them unreasonable to hold or immoral. Thus, the paradox is avoided by clarifying the acceptance, objection and rejection components of toleration with the help of a distinction between moral and ethical justification.

The second paradox says that toleration, as soon as its limits are defined by a certain content, becomes intolerant toward those 'outside'. As an answer to this, everything depends on whether one wants to call both the suppression of any form of dissent and the suppression of this form of suppression 'intolerance'. But this seems a misuse of the term: we cannot call any form of moral critique 'intolerance', because then we lose the concept of toleration completely. Instead, by drawing the 'limits of toleration' with 
the help of the criteria of reciprocity and generality, we draw them, as I have tried to argue, in the widest possible way given the existence of a large diversity of world-views, without sacrificing one for the sake of the unjustifiable claims of another. Thus there is no arbitrary substantive content that defines the tolerable; this content is open to dispute and argument, and protection is given to those voices in danger of being marginalised. ${ }^{35}$ Those who violate the basic form of mutual respect implied by that cannot claim to be the victims of intolerance. For otherwise, not only the concept of toleration, but also the concept of justice would lose its meaning.

\section{Notes}

A version of this chapter was published as 'Toleranz, Gerechtigkeit und Vernunft' in R. Forst (ed.), Toleranz. Philosophische Grundlagen und gesellschaftliche Praxis einer umstrittenen Tugend (Frankfurt/Main: Campus, 2000), pp. 119-43. For helpful comments on various versions of my argument I want to thank especially Joel Anderson, Dario Castiglione, Richard Dees, Günter Frankenberg, Elisabetta Galeotti, Jürgen Habermas, Axel Honneth, Otto Kallscheuer, Andreas Kuhlmann, Charles Larmore, Catriona McKinnon, Donald Moon and Henry Richardson.

1 Here I make use of a distinction that John Rawls has suggested concerning the concept of justice: see J. Rawls, A Theory of Justice (Cambridge, MA: Harvard University Press, 1971), p. 5.

2 P. King, Toleration (New York: St Martin's Press, 1976), Ch. 1.

3 The term 'objection' entails a difficult problem that I can only indicate here briefly. The objection needs to be normatively justifiable (though not generally sharable) in some sense, and must not be based on mere prejudice. If, for example, somebody finds members of a different 'race' generally objectionable and inferior, one cannot simply ask him or her to be 'tolerant', since that would mean to accept his racist prejudice as a possible objection. On this, see B. Crick, 'Toleration and tolerance in theory and practice', Government and Opposition, 6 (1971) 144-71, and especially J. Horton, 'Toleration as a virtue', in D. Heyd (ed.), Toleration: An Elusive Virtue (Princeton, NJ: Princeton University Press, 1996), pp. 28-43.

4 D. D. Raphael, 'The intolerable', in S. Mendus (ed.), Justifying Toleration. Conceptual and Historical Perspectives (Cambridge: Cambridge University Press, 1988), pp. 137-54; S. Mendus, Toleration and the Limits of Liberalism (Atlantic Highlands, NJ: Humanities Press, 1989), pp. 18-20. An earlier formulation of this can be found in Julius Ebbinghaus, 'Über die Idee der Toleranz', Archiv für Philosophie 4 (1950) 1-34.

5 On this point, I agree with Glen Newey, Virtue, Reason and Toleration: The Place of Toleration in Ethical and Political Philosophy (Edinburgh: Edinburgh University Press, 1999), pp. 32-4, from whom I differ fundamentally, however, in the understanding of the nature of the reasons for objection.

6 See especially S. Fish, 'Mission impossible: Settling the just bounds between Church and State', Columbia Law Review 97 (1997) 2255-333; and Martha Minow, 'Putting up and putting down: Tolerance reconsidered', in M. Tushnet (ed.), Comparative Constitutional Federalism. Europe and America (New York: Greenwood Press, 1990), pp. 77-113. 
7 See B. Williams, 'Toleration: An impossible virtue?', in Heyd (ed.), Toleration, pp. $18-27$.

8 See M. Walzer, On Toleration (New Haven, CT: Yale University Press, 1997).

9 I have analysed such a conflict in my discussion of the so-called 'crucifix-case' decided by the Federal Constitutional Court in Germany in 1995: see R. Forst, 'A tolerant Republic?', in J.-W. Müller (ed.), German Ideologies since 1945 (New York: St Martin's Press, forthcoming).

10 J. W. Goethe, 'Maximen und Reflexionen', in Werke 6 (Frankfurt/Main, Insel, 1981), p. 507: 'Toleranz sollte nur eine vorübergehende Gesinnung sein: sie muß zur Anerkennung führen. Dulden heißt beleidigen.'

11 See E. Garzón Valdés, 'Some remarks on the concept of toleration', Ratio Juris 10 (1997) 127-38.

12 See J. Rawls, 'The idea of an overlapping consensus', Oxford Journal of Legal Studies 7 (1987) 1-25, at p. 11; George Fletcher, 'The instability of tolerance', in Heyd (ed.), Toleration, pp. 158-72.

13 On the idea of such a development see Richard H. Dees, 'The justification of tolerance', in G. Magill and M. D. Hoff (eds), Values and Public Life (Lanham, MD: University Press of America, 1995), pp. 29-56.

14 See T. Scanlon, 'The difficulty of tolerance', in Heyd (ed.), Toleration, pp. 226-39; Y. Yovel, 'Tolerance as grace and as rightful recognition', Social Research 65 (1998) 897-919; N. Bobbio, 'Gründe für die Toleranz', in Das Zeitalter der Menschenrechte (Berlin: Wagenbach, 1998), pp. 87-106.

15 See my discussion of neutrality in R. Forst, Contexts of Justice. Political Philosophy beyond Liberalism and Communitarianism, trans. J. M. M. Farrell (Berkeley and Los Angeles, CA: University of California Press, 2002), Ch. 2. Note that in this characterisation of the respect conception the main argument for respect is not the liberal one that persons are to be seen as ethically autonomous authors of their own lives and that tolerance is demanded because persons have a right to such a kind of ethical autonomy as a necessary condition for the good life. Such a justification of toleration, I believe, is based on a non-generalisable conception of the good and is caught in the dilemma of either regarding individual choices per se as worthy of respect (which leads to an extremely wide view of toleration) or of tolerating only beliefs and practices that are authentically self-chosen (which leads to a very narrow view). As I will argue below, the respect conception should rather be based on the more fundamental notion of moral autonomy (and the right of each moral person to a justification of general norms he or she is subject to). For a discussion of the distinction between various conceptions of autonomy see R. Forst, 'Political liberty: Integrating five conceptions of autonomy', in J. Christman and J. Anderson (eds), Autonomy and the Challenges to Liberalism: New Essays (currently in preparation).

16 See A. E. Galeotti, 'Citizenship and equality: The place for toleration', Political Theory 21 (1993) 585-605.

17 On the justification of these limits see my debate with Will Kymlicka: R. Forst, 'Foundations of a theory of multicultural justice', Constellations 4 (1997) 63-71, and W. Kymlicka, 'Do we need a liberal theory of minority rights? A reply to Carens, Young, Parekh and Forst', ibid., pp. 72-87.

18 See, for example, the (very different) views of Z. Bauman, Modernity and Ambivalence (Oxford: Polity, 1991); Julia Kristeva, Strangers to Ourselves (New 
York, Columbia University Press, 1991); and Karl-Otto Apel, 'Plurality of the good? The problem of affirmative tolerance in a multicultural society from an ethical point of view', Ratio Juris 10 (1997) 199-212.

19 See J. Raz, 'Autonomy, toleration, and the harm principle', in S. Mendus (ed.), Justifying Toleration, pp. 155-75, on moral pluralism as a basis for toleration; or Michael Sandel, 'Moral argument and liberal toleration: Abortion and homosexuality', California Law Review 77 (1989) 521-38, on the toleration of variations of established cultural practices.

20 See esp. Rawls, A Theory of Justice, sections 34 and 35, on the relation between toleration and justice.

21 For an extensive discussion see Forst, Contexts of Justice.

22 Here I use a phrase by Thomas Scanlon, interpreting it with the help of the criteria of reciprocity and generality, something that Scanlon does not do, at least explicitly; cf. his 'Contractualism and utilitarianism', in A. Sen and B. Williams (eds), Utilitarianism and beyond (Cambridge: Cambridge University Press, 1982), pp. 103-128, and What We Owe to Each Other (Cambridge, MA: Harvard University Press, 1998), Chs. 4 and 5.

23 This distinction has been suggested by Jürgen Habermas: see especially his 'On the Pragmatic, the Ethical, and the Moral Employments of Practical Reason', in Justification and Application, trans C. Cronin (Cambridge, MA: MIT Press, 1993), pp. 1-17. For a recent discussion (which points out the differences with Habermas's view) see Forst, 'Ethik und Moral', in L. Wingert and K. Günther, Die Öffentlichkeit der Vernunft und die Vernunft der Öffentlichkeit (Frankfurt/Main: Suhrkamp, 2001), pp. 344-71.

24 See T. Nagel, 'Moral conflict and political legitimacy', Philosophy and Public Affairs 16 (1987) 215-40, and Equality and Partiality (New York: Oxford University Press, 1991), pp. 154ff.; John Rawls, Political Liberalism (New York: Columbia University Press, 1993), pp. 58ff.

25 See C. Taylor, 'Explanation and Practical Reason', in M. Nussbaum and A. Sen (eds), The Quality of Life (New York: Oxford University Press, 1993), pp. 208-31.

26 I discuss a number of examples in Forst, 'The Limits of Toleration', in I. Creppell, S. Macedo, and R. Hardin, Toleration and Identity Conflict (currently in preparation).

27 This does not imply that religious arguments have no legitimate role in public political discourse; it merely says that they should not be the basis of generally binding law if they cannot pass the test of reciprocity and generality.

28 On this point, see Raz's critique of Nagel's view: J. Raz, 'Facing diversity: The case of epistemic abstinence', Philosophy and Public Affairs 19 (1990) 3-46.

29 See C. Larmore, 'Pluralism and reasonable disagreement', in The Morals of Modernity (Cambridge: Cambridge University Press, 1996), pp. 152-74.

30 I therefore disagree with Brian Barry, Justice as Impartiality (Oxford: Oxford University Press, 1995), pp. 168-73, who argues that the acceptance of what he calls the 'burden of public justification' presupposes an ethical scepticism such that 'no conception of the good can justifiably be held with a degree of certainty that warrants its imposition on those who reject it' (p. 169). The kind of selfrestraint Barry has in mind here first of all seems to be based on a moral rather than a sceptical insight, for one can of course be convinced of the truth of certain beliefs and still not think that one is justified in imposing them on others; the 
willingness to impose one's beliefs would be a rather odd criterion for sincere belief. Furthermore, somebody with a certain religious faith need not, it seems to me, assume that the fact that there is so much disagreement in religious matters is an argument either against the truth of his or her beliefs or against the reasonableness of those who disagree. The relation between 'reason' and 'faith' is much more complex than this, as is argued for instance by Montaigne, who was at the same time a sceptic and a fideist. Sebastian Franck, Sebastian Castellio and Jean Bodin are other examples from post-Reformation Europe, to which period Barry refers. I discuss their views on toleration in Chapters 3 and 4 of my forthcoming Toleranz im Konflikt.

31 Rawls, Political Liberalism, p. 55.

32 See J. S. Mill, On Liberty, ed. G. Himmelfarb (Harmondsworth, Penguin, 1974) and K. Popper, 'Toleration and intellectual responsibility', in S. Mendus and D. Edwards (eds), On Toleration (Oxford: Clarendon, 1987), pp. 17-34.

33 See C. Korsgaard, 'The reasons we can share', in Creating the Kingdom of Ends (Cambridge: Cambridge University Press, 1996), pp. 275-310.

34 This leads to a very important point (which, however, I cannot spell out here). Given the need to apply philosophical concepts to philosophy itself, a conception of toleration can only be justifiable if it is itself tolerant toward the different ethical world-views that persons hold (a point stressed by Rawls); and these world-views imply different accounts of ethical knowledge, value, and reality. Therefore one would have to show that the conception of toleration I have just explained with respect to its normative and epistemological elements is the conception that leaves the widest possible room for various ways of conceiving the moral world and of explaining the reasons for toleration in a more particular way. On this, see my Toleranz im Konflikt, Part II.

35 Needless to say, this calls for a theory of democracy as part of a political theory of toleration. See, for example, James Bohman, 'Reflexive Toleration in a Deliberative Democracy', in this volume. 